\title{
Andrew Watt, M.A.
}

ANDREW WATT was born in Edinburgh in 1869 , and was educated at Dumfries Academy and afterwards at Edinburgh University, where in 1888 he was Medallist of the Senior Mathematics Class. After graduating he went out to Australia and taught mathematics in the Scots College, Melbourne, until 1894, when he returned to this country. He continued in the teaching profession until his appointment in 1900 to the staff of the Scottish Meteorological Society as Assistant to the late Dr Buchan. On Dr Buchan's death in 1907 Watt became Secretary to the Meteorological Society; and indeed for some time prior to that the general work of the Society had largely devolved on him. He edited the Society's Journal, which maintained a high standard of usefulness, and not a few of the articles which it contained were from his pen. His chief papers were on rainfall and climate. Occasionally he gave lectures under the auspices of the Meteorological Society on subjects of meteorological interest, and the success of these was to him ample reward for the labour that went to their preparation.

In 1920 the climatological work hitherto done by the Scottish Meteorological Society was taken over by the Meteorological Office, and the Society was amalgamated with the Royal Meteorological Society. Watt loyally assisted in carrying through these changes, and in the new conditions continued to give cheerfully of his best.

From the loss of his wife (formerly Miss Winifred Attwell) in August 1927, after a prolonged illness, Andrew Watt seemed never fully to recover; but the sudden nature of his own end (which came on the evening of 9th January, after he had attended to his daily duties as usual) was quite unexpected.

In Andrew Watt a kindly nature and a willingness to be of assistance were ever dominant, and these contributed in no small measure towards holding together the organisation of voluntary meteorological observers on whom the Meteorological Service so greatly depends. Watt was approaching the age limit for the Service, and his friends could have wished that he had lived to complete his full period and to enjoy the leisure of retirement.

$\mathrm{He}$ is survived by his younger brother, James Watt, C.M.G., and two sisters.

He was elected a Fellow of the Society in 1907.

A. H. R. G. 